\title{
In Vitro Assessment of Biofield Energy Healing Treatment on Hair Growth by Enhanced Proliferation of Human Follicular Dermal Papilla Cells (HFDPCs)
}

\author{
Dahryn Trivedi ${ }^{1}$, Snehasis Jana ${ }^{2 *}$ \\ ${ }^{1}$ Trivedi Global, Inc, Henderson, Nevada, USA \\ ${ }^{2}$ Trivedi Science Research Laboratory Pvt. Ltd, Bhopal, Madhya Pradesh, India
}

*Corresponding author: Snehasis Jana, Trivedi Science Research Laboratory Pvt Ltd, Bhopal, Madhya Pradesh, India, Email: publication@trivedieffect.com

\begin{abstract}
Patterned hair loss or androgenic alopecia is a disorder affecting millions of peoples, in which hair sheds without adequate regrowth. Authors propose a new approach to increase hair growth. In this study, authors examined the in vitro potential of the Biofield Energy Healing (The Trivedi Effect ${ }^{\circledR}$ ) Treated test items, Dulbecco's Modified Eagle Medium (DMEM) on the Human Follicular Dermal Papilla Culture Cells (HFDPC) for the assessment of growth and development.

The test items (DMEM) were divided into three parts. First part did not receive any sort of treatment and defined as the untreated DMEM group. The second and third parts were treated with the one-time and two-times Biofield Energy Treatment by a renowned Biofield Energy Healer, Dahryn Trivedi and coded as the one-time Biofield Energy Treated DMEM (BT-I) and two-times Biofield Energy Treated DMEM (BT-II) groups, respectively. The Biofield Energy Healing Treatment was provided by a renowned Biofield Energy Healer (The Trivedi Effect ${ }^{\circledR}$ ), remotely for $\sim 5$ minutes under standard laboratory conditions through unique energy transmission process. The experimental results showed that one-time Biofield Energy Treated DMEM showed 70.24\% and two-times Biofield Energy Treated DMEM significantly ( $p \leq 0.001$ ) increased the proliferation of dermal papilla cells by $207.62 \%$ as compared to the untreated DMEM group. The overall results demonstrated that the Biofield Energy Healing Treatment significantly increased the proliferation of human hair follicle dermal papilla cells in vitro. Therefore, the Consciousness Energy Healing (The Trivedi Effect ${ }^{\circledR}$ ) Treatment might be useful as a hair growth promoter in vivo against different types of skin injuries, hair disorders, and opens new research venues.
\end{abstract}

Keywords: Biofield Energy Treatment; The Trivedi Effect ${ }^{\circledR}$; Dermal papilla cell; Skin health; Hair health

\section{Introduction}

Growth and maintenance of healthy hair is a cyclical process. The hair cycle consists of three different stages such as an active growing phase (anagen), an intermediate regressive (catagen) phase and a resting phase (telogen) during which no cell proliferation oc$\operatorname{curs}^{[1,2]}$. The growth of hair follicles is regulated by a number of factors, including sensory neurons, cytokines, growth factors, and androgens (testosterone and dihydrotestosterone) ${ }^{[3,4]}$. Change of the hair cycle and the progressive miniaturization of the regrowth leads to overall hair $\operatorname{loss}^{[5]}$. About 16\% males (the age between 18 to 29 years) and 53\% males (the age between 40 to 49 years) are suffering from androgenic hair loss ${ }^{[6]}$. Moreover, females are equal or oftenless affected by androgenic alopecia, but alopecia areata is observed amongst females ${ }^{[7]}$ Minoxidil is a common hair re-growth product that has been shown to work via growth factor release from adipose-derived stem cells, dermal papilla, and epithelial cells ${ }^{[8]}$.

Based on studies on the correlation of electric current with physiological process reported that every single process in the human body had an electrical significance ${ }^{[9]}$. According to Rivera-Ruiz et al. 2008, that electrocardiography has been extensively used to
Received date: November 11, 2018 Accepted date: November 20, 2018 Published date: November 25, 2018

Citation: Trivedi, D., et al. In Vitro Assessment of Biofield Energy Healing Treatment on Hair Growth by Enhanced Proliferation of Human Follicular Dermal Papilla Cells (HFDPCs) (2018) Invest Demerol and Venereol Res 4(1): 30- 44.

Copy Rights: (C) 2018 Trivedi, D. This is an Open access article distributed under the terms of Creative Commons Attribution 4.0 International License. 
measure the Biofield of the human body ${ }^{[10]}$. Thus, the cumulative effect of bio-magnetic field and electric field surrounds the human body is defined as biofield. The energy associated with this field is considered as biofield energy and it can also be monitored using Electro Myo Graphy (EMG) and Electro Encephalo Gram (EEG $)^{[11]}$. In recent years, several scientific reports have revealed the useful effects of Biofield Energy Treatment, which have shown to enhance the immune function in patients with cervical cancer via therapeutic touch ${ }^{[12]}$, and massage therapy ${ }^{[13]}$. Complementary and Alternative Medicine (CAM) therapies are now rising as preferred models of treatment, among which Biofield Therapy (or Healing Modalities) is one approach that has been reported to have several human benefits to enhance physical, mental and emotional wellness. However, as per the data of 2017 from the National Health Interview Survey (NHIS), which indicated that more than $20 \%$ of Americans use dietary supplements as a complementary health approach ${ }^{[14]}$. Additionally, other medicines and practices are employed, such as natural products, deep breathing, yoga, Tai Chi, Qi Gong, chiropractic / osteopathic manipulation, meditation, massage, special diets, homeopathy, progressive relaxation, guided imagery, acupressure, acupuncture, other relaxation techniques, hypnotherapy, healing touch, movement therapy, Pilates, Rolfing structural integration, mindfulness, Ayurvedic medicine, traditional Chinese herbs / medicine, naturopathy, essential oils, aromatherapy, Reiki, and cranial sacral therapy. The National Center of Complementary and Integrative Health (NCCIH) has recognized and accepted Biofield Energy Healing as a CAM health care approach ${ }^{[15]}$. Human Biofield Energy has subtle energy that has the capacity to work in an effectively ${ }^{[16]}$. CAM therapies have been practiced worldwide with reported clinical benefits in different diseases ${ }^{[17]}$. Biofield Energy can be harnessed and transmitted by the experts into living and non-living things via the process of Biofield Energy Healing Transmission. The Trivedi Effect ${ }^{\mathbb{}}$-Consciousness Energy Healing Treatment has been reported with a significant effect on the physicochemical properties of metals, chemicals, ceramics, and polymers ${ }^{[18-20]}$, improved agricultural crop yield, productivity, and quality ${ }^{[21,22]}$, and transformed antimicrobial characteristics $^{[23-25]}$, biotechnology ${ }^{[26,27]}$, improved bioavailability $^{[28-30]}$, skin health ${ }^{[31,32]}$, nutraceuticals ${ }^{[33,34]}$, cancer research ${ }^{[35,36]}$, bone health ${ }^{[37-39]}$, human health and wellness. Based on the literature information and the importance of Biofield Energy Healing Treatment on various fields, the authors sought to evaluate the impact of the Biofield Energy Treatment (The Trivedi Effect ${ }^{\circledR}$ ) on androgenic alopecia, specifically for human dermal papilla cell growth activity using a standard assay.

\section{Materials and Methods}

Chemicals and Reagents: Dulbecco's Modified Eagle Medium (DMEM) and Fetal Bovine Serum (FBS) were obtained from Gibco, India. 3-(4, 5-Dimethylthiazol-2-yl)-2,5-Diphenyltetrazolium Bromide (MTT) and Ethylene Diamine Tetra Acetic Acid (EDTA) were obtained from Sigma Chemical Co. (St. Louis, MO). Minoxidil sulphate (positive control) was purchased from Clearsynth Labs Ltd., Mumbai. Antibiotics solution (penicillin-streptomycin) was procured from HiMedia, India. Other chemicals used in this study were analytical grade and obtained from India.

\section{BrdU Incorporation Cell Proliferation Assay in HFDPCs:}

The human follicular dermal papilla cells (HFDPCs) in DMEM supplemented with $10 \%$ FBS were counted using a hemocytometer and a single cell suspension was prepared. The single cell suspension was seeded at a density of 800 cells / well in a fresh DMEM supplemented with $10 \%$ FBS in 96 -well plates. Then, the cells were incubated in a $\mathrm{CO}_{2}$ incubator for 24 hours at $37^{\circ} \mathrm{C}$, $5 \% \mathrm{CO}_{2}$, and $95 \%$ humidity. After 24 hours of incubation, the medium was replaced with a fresh DMEM supplemented with $0.1 \%$ FBS. Further, after 24 hours, cells were treated with the test items and positive control (minoxidil sulphate). After incubation for 48 hours, the effect of the test items on cell proliferation was assessed by Bromodeoxyuridine (BrdU) incorporation using colorimetric ELISA kit. For that, $10 \mu \mathrm{L}$ of BrdU solution was added per well and the cells were incubated for 90 minutes at $37^{\circ} \mathrm{C}$. After incubation, the medium was removed from each well by gentle pipetting. About $200 \mu \mathrm{L}$ of a FixDenat solution was added to each well. After incubation, cells were incubated for 30 minutes at Room Temperature (RT) $\left(15-25^{\circ} \mathrm{C}\right)$. The FixDenat solution was removed by gentle pipetting. After incubation, $100 \mu \mathrm{L}$ of anti-BrdU-POD (peroxidase) solution was added to each well. Then, the cells were incubated for 90 minutes at RT $\left(15-25^{\circ} \mathrm{C}\right)$. After incubation, the anti-BrdU-POD solution was removed by gentle pipetting. Each well was washed 3 times using $200 \mu \mathrm{L}$ of washing solution. About $100 \mu \mathrm{L}$ of substrate solution was added to each well. Cells were incubated for 30 minutes at RT $\left(15-25^{\circ} \mathrm{C}\right)$. After incubation, the absorbance of each well was measured at $370 \mathrm{~nm}$.

Cellular proliferation was determined as following Equation (1):

$\%$ Cellular proliferation $=\{(\mathrm{B}-\mathrm{A}) / \mathrm{A}\} \times 100 \ldots$

Where, $\mathrm{A}=\mathrm{OD}$ of Untreated DMEM wells

$\mathrm{B}=\mathrm{OD}$ of cells treated with the test items/positive control

Experimental Design: The experimental groups composed of group 1 (G-I) with DMEM medium defined as the untreated DMEM group. Group 2 (G-II) contained positive control (minoxidil sulphate) at various concentrations. Further, group 3 (G-III) included one-time Biofield Energy Treated DMEM and denoted as BT-I, while group 4 (G-IV) included the two-times Biofield Energy Treated DMEM and denoted as BT-II.

Biofield Energy Healing Strategy: The test item, DMEM was divided into three parts. First part did not receive any sort of treatment and defined as the untreated DMEM group. The second and third parts were treated with the one-time and two-times Biofield Energy Treatment by a renowned Biofield Energy Healer (The Trivedi Effect ${ }^{\circledR}$ ), Dahryn Trivedi remotely for $\sim 5$ minutes under laboratory conditions and coded as the one-time Biofield Energy Treated DMEM (BT-I) and two-times Biofield Energy Treated DMEM (BT-II) groups, respectively. The healer in this study never visited the laboratory in person, nor had any contact with the test items (DMEM medium). Further, the untreated DMEM group was treated with a "sham" healer for comparative purposes. The "sham" healer did not have any knowledge about the Biofield Energy Treatment. After that, the Biofield Energy Treated and untreated test items were kept in similar sealed conditions for experimental study. 
Statistical Analysis: All the values were represented as Mean \pm SEM (Standard Error of Mean) of three independent experiments. The statistical analysis was performed using SigmaPlot statistical software (v11.0). For two group comparisons the student's $t$-test was used. For multiple group comparison, one-way analysis of variance (ANOVA) was used followed by post-hoc analysis by Dunnett's test. Statistically significant values were set at the level of $p \leq 0.05$.

\section{Results and Discussion}

Proliferation of Dermal Papilla Cells: Human hair growth is a unique repetitive cycle of initiation (anagen), regression (catagen), and shifting of hair bulb (telogen). Dermal Papilla Cells (DPCs) can influence the regulation of hair follicle development and periodic regeneration. Alteration of normal physiology of DPCs can cause hair loss ${ }^{[40-43]}$. The follicular morphogenesis and hair growth also depend on the interaction between the epithelial and mesenchymal cells of hair follicles ${ }^{[44,45]}$. Topical application of minoxidil is a well-established therapeutic for various types of hair growth-related disorders like androgenic alopecia ${ }^{[46]}$. The immortalized human follicular dermal papilla cells suspension was treated with the positive control and test items (DMEM). The percent increase of DPCs in the test items and positive control is shown in Figure 1. The study results revealed that the percent proliferation of DPCs in the untreated DMEM group was $100 \%$. Moreover, the percent proliferation of DPCs was significantly $(p \leq 0.001)$ increased in a concentration-dependent manner by $68.57 \%, 187.14 \%$, and $230.95 \%$ at $0.001,0.01$, and $0.1 \mu \mathrm{M}$, respectively, in the positive control (minoxidil) group compared to the untreated DMEM group. Furthermore, one-time Biofield Energy Treated DMEM group (BT-I) showed 70.24\%, while two-times Biofield Energy Treated DMEM group (BTII) showed significantly increased proliferation of DPCs by $207.62 \%$ with respect to the untreated DMEM group (Figure 1). Here, the findings clearly anticipated that Biofield Energy Treatment significantly enhanced the percent proliferation of DPCs.

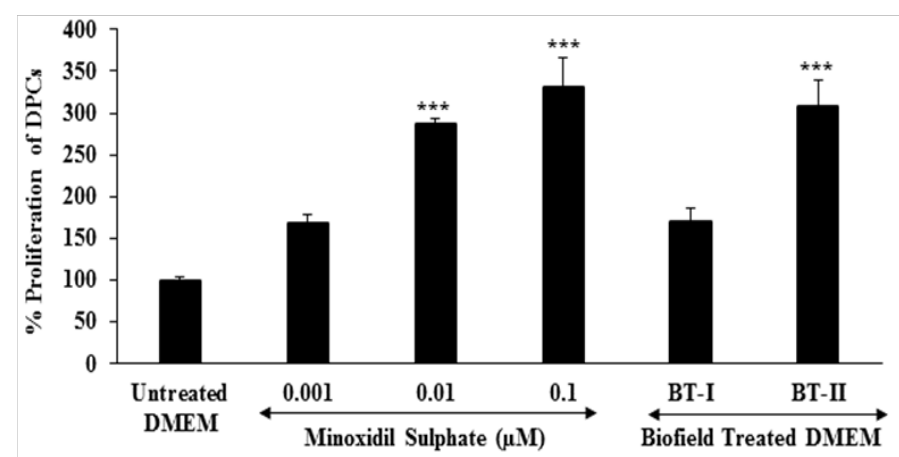

Figure 1: Effect of the test samples on hair growth regarding dermal papilla cells (DPCs) proliferation after 48 hours of treatment in immortalized human follicular dermal papilla cell line (HFDPC). BT-I: One-time Biofield Energy Treated DMEM; BT-II: Two-times Biofield Energy Treated DMEM. All the values are represented as mean \pm SEM of three independent experiments. ${ }^{* * *} p \leq 0.001 v s$. untreated DMEM group.

Besides, some representative photo micro graphs showed the intensity of proliferative DPCs after treatment with the test items (DMEM) in HFDPC (Figure 2). Overall, data showed that two-times Biofield Energy Treatment remarkably improved the growth and proliferation of human dermal papilla cells in vitro. Based on that it is concluded that, two-times Biofield Energy Treatment could be more advantageous than onetime transmission of Consciousness Energy Therapy to maintain a steady-state proliferation of hair follicles.
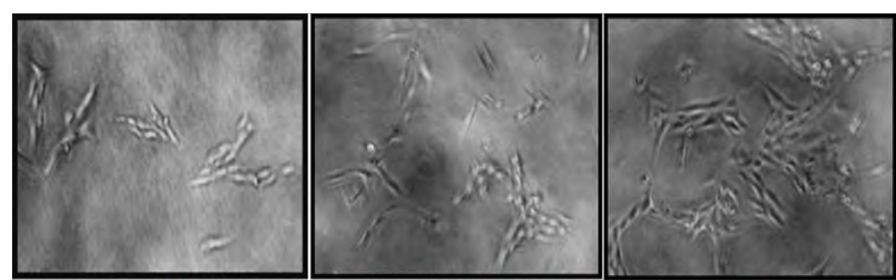

Untreated DMEM Minoxidil $(0.001 \mu \mathrm{M})$ Minoxidil $(0.01 \mu \mathrm{M})$

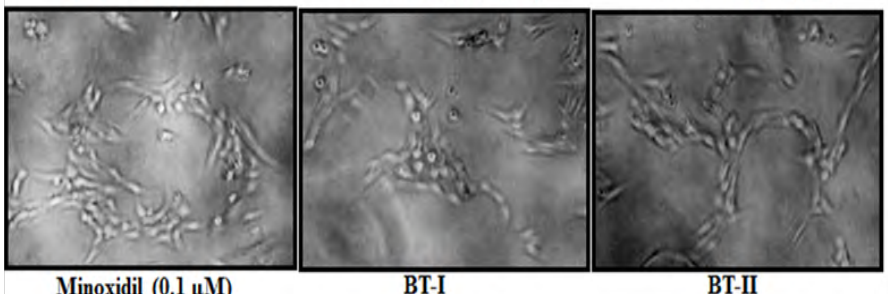

Minoxidil $(0.1 \mu \mathrm{M})$ BT-I BT-II

Figure 2: Effect of Biofield Energy Treated DMEM on the proliferation of dermal papilla cells (DPCs) in Human Follicular Dermal Papilla Cell Line (HFDPC) and the representative images of different treatment groups. BT-I: One-time Biofield Energy Treated DMEM; BT-II: Twotimes Biofield Energy Treated DMEM

\section{Conclusion}

The experimental results showed that one-time and two-times Biofield Energy Treated test items (DMEM) group showed $70.24 \%$ and $207.62 \%$ increase of Human Dermal Papilla Cells (DPCs), respectively, in vitro. Overall, Biofield Energy Treated test items significantly enhanced the DPCs. In conclusion, The Trivedi Effect ${ }^{\circledR}$-Consciousness Energy Healing Treatment might act as an effective hair growth enhancer and it can be used as a complementary and alternative treatment for the prevention of various types of skin and hair-related disorders like necrotizing fasciitis, actinic keratosis, sebaceous cysts, diaper rash, decubitus ulcer, androgenetic alopecia, telogen effluvium, trichodystrophy, alopecia areata, etc. Besides, it could be useful to improve cell-to-cell communication, normal cell growth, cell differentiation, neurotransmission, cell cycling and proliferation, hormonal balance, skin health, immune and cardiovascular functions. Moreover, it can potentially be utilized in organ transplants (i.e., kidney transplants, liver transplants and heart transplants), hormonal imbalance, aging, and various immune-related disease conditions such as Ulcerative Colitis (UC), Alzheimer's Disease (AD), dermatitis, Irritable Bowel Syndrome (IBS), asthma, Hashimoto Thyroiditis, pernicious anemia, Sjogren Syndrome, multiple sclerosis, aplastic anemia, hepatitis, diverticulitis, Graves' Disease, dermatomyositis, diabetes, myasthenia gravis, Parkinson's Disease, atherosclerosis, Systemic Lupus Erythematosus (SLE), stress, etc. with a safe therapeutic index to improve overall health and the quality of life.

Acknowledgements: Authors gratefully acknowledged to Trivedi Global, Inc., Trivedi Science, Trivedi testimonials and Trivedi master wellness for their support. In addition, authors are thankful for the support of Dabur Research Foundation for conducting this study. 
Citation: Trivedi, D., et al. In Vitro Assessment of Biofield Energy Healing Treatment on Hair Growth by Enhanced Proliferation of Human Follicular Dermal Papilla Cells (HFDPCs) (2018) Invest Demerol and Venereol Res 4(1): 45- 49.

Abbreviations: CAM: Complementary and Alternative Medicine; DPCs: Dermal Papilla Cells; DMEM: Dulbecco's Modified Eagle Medium; FBS: Fetal Bovine Serum; BrdU: Bromodeoxyuridine; POD: Peroxidase

\section{References}

1. Philpott, M.P., Green, M.R., Kealey, T. Human hair growth in vitro. (1990) J Cell Sci 97(3): 463-471. Pubmed| Crossref] Others

2. Hoffmann, R., Happle, R. Current understanding of androgenetic alopecia. Part II: Clinical aspects and treatment. (2000) Eur J Dermatol 10(5): 410- 417. Pubmed| Crossref| Others

3. Paus, R., Cotsarelis, G. The biology of hair follicles. (1999) N Engl J Med 341(1): 491- 497. Pubmed| Crossref| Others

4. Stenn, K.S., Paus, R. Controls of hair follicle cycling. (2001) Physiol Rev 81(1): 449- 494.

Pubmed| Crossref| Others

5. Courtois, M., Loussouarn, G., Hourseau, C., et al. Hair cycle and alopecia. (1994) Skin Pharmacol 7(1-2): 84-89. Pubmed| Crossref| Others

6. Rhodes, T., Girman, C.J., Savin, R.C., et al. Prevalence of male pattern hair loss in 18-49 year old men. (1998) Dermatol Surg 24(12):1330-1332. Pubmed| Crossref| Others

7. Goldstein, B.G., Goldstein, A.O. Patient education: Hair loss in men and women (androgenetic alopecia) (Beyond the Basics). (2018).

Pubmed| Crossref| Others

8. Choi, N., Shin, S., Song, S.U., et al. Minoxidil promotes hair growth through stimulation of growth factor release from adipose-derived stem cells. (2018) Int J Mol Sci 19(3): 691. Pubmed| Crossref| Others

9. Burr, H.S. Bibliography of Harold Saxton Burr. (1957) Yale J Biol Med 30(3): 163-167.

Pubmed| Crossref| Others

10. Rivera-Ruiz, M., Cajavilca, C., Varon, J. Einthoven's String Galvanometer: the first electrocardiograph. (2008) Tex Heart Inst J 35(2):174-178.

Pubmed| Crossref| Others

11. Zahra, M. Farsi, M. Biofield therapies: Biophysical basis and biological regulations. (2009) Complement Ther Clin Pract 15(1): 35-37.

Pubmed| Crossref| Others

12. Lutgendorf, S.K., Mullen-Houser, E., Russell, D., et al. Preservation of immune function in cervical cancer patients during chemoradiation using a novel integrative approach. (2010) Brain Behav Immun 24(8): 1231-1240. Pubmed| Crossref| Others

13. Ironson, G., Field, T., Scafidi, F., et al. Massage therapy is associated with enhancement of the immune system's cytotoxic capacity. (1996) Int J Neurosci 84(1-4): 205-217. Pubmed| Crossref| Others

14. Sunjka, M.L., Pejcic, A., Jakovljevic, M. Utilization patterns of complementary and alternative medicine in Australia, Canada and the United States: Popularity of dietary supplements, mindbody and manipulative therapies. (2017)
Farmeconomia 18(1): 15-20.

Pubmed| Crossref| Others

15. Galantino, M.L., Muscatello, L. The psychoneuroimmunology connection. (2011) Energy Medicine East.

Pubmed| Crossref| Others

16. Jain, S., Hammerschlag, R., Mills, P., et al. Clinical studies of biofield therapies: Summary, methodological challenges, and recommendations. (2015) Glob Adv Health Med 4: 5866.

Pubmed| Crossref| Others

17. Rubik, B. The biofield hypothesis: Its biophysical basis and role in medicine. (2002) J Altern Complement Med 8(6): 703-717.

Pubmed| Crossref| Others

18. Trivedi, M.K., Tallapragada, R.M. A transcendental to changing metal powder characteristics. (2008) Met Powder Rep 63(9): 22-28,31.

Pubmed| Crossref| Others

19. Trivedi, M.K., Nayak, G., Patil, S., et al. Studies of the atomic and crystalline characteristics of ceramic oxide nano powders after bio field treatment. (2015) Ind Eng Manage 4: 161 .

Pubmed| Crossref| Others

20. Trivedi, M.K., Nayak, G., Patil, S., et al. Effect of biofield energy treatment on physical and structural properties of calcium carbide and praseodymium oxide. (2015) Int J Materials Sci Appl 4(6): 390-395.

Pubmed| Crossref| Others

21. Trivedi, M.K., Branton, A., Trivedi, D., et al. Morphological characterization, quality, yield and DNA fingerprinting of biofield energy treated alphonso mango (Mangifera indica L.). (2015) J Food Nutrition Sci 3(6): 245-250.

Pubmed| Crossref| Others

22. Trivedi, M.K., Branton, A., Trivedi, D., et al. Evaluation of biochemical marker - Glutathione and DNA fingerprinting of biofield energy treated Oryza sativa. (2015) Ame J BioSci 3(6): 243-248.

Pubmed| Crossref| Others

23. Trivedi, M.K., Branton, A., Trivedi, D., et al. Phenotyping and $16 \mathrm{~S}$ rDNA analysis after biofield treatment on Citrobacter braakii: A urinary pathogen. (2015) J Clin Med Genom 3(1): 129.

Pubmed| Crossref| Others

24. Trivedi, M.K., Patil, S., Shettigar, H., et al. Evaluation of biofield modality on viral load of Hepatitis $\mathrm{B}$ and $\mathrm{C}$ viruses. (2015) J Antivir Antiretrovir 7(3): 83-88.

Pubmed| Crossref| Others

25. Trivedi, M.K., Patil, S., Shettigar, H., et al. An impact of biofield treatment: Antimycobacterial susceptibility potential using BACTEC 460/MGIT-TB System. (2015) Mycobact Dis 5: 189.

Pubmed| Crossref| Others

26. Trivedi, M.K., Patil, S., Shettigar, H., et al. Phenotypic and biotypic characterization of Klebsiella oxytoca: An impact of biofield treatment. (2015) J Microb Biochem Technol 7: 202-205.

Pubmed| Crossref| Others

27. Nayak, G., Altekar, N. Effect of biofield treatment on plant growth and adaptation. (2015) J Environ Health Sci 1(2): $1-9$. 
Pubmed| Crossref| Others

28. Branton, A., Jana, S. The influence of energy of consciousness healing treatment on low bioavailable resveratrol in male Sprague Dawley rats. (2017) Int J Clin Developmental Anatomy 3(3): 9-15.

Pubmed| Crossref| Others

29. Branton, A., Jana, S. The use of novel and unique biofield energy healing treatment for the improvement of poorly bioavailable compound, berberine in male Sprague Dawley rats. (2017) Ame J Clinical Experimental Med 5(4): 138144.

Pubmed| Crossref| Others

30. Branton, A., Jana, S. Effect of The biofield energy healing treatment on the pharmacokinetics of 25-hydroxyvitamin D3 $\left[25(\mathrm{OH}) \mathrm{D}_{3}\right]$ in rats after a single oral dose of vitamin D3. (2017) Ame J Pharmacology Phytotherapy 2(1): 11-18. Pubmed| Crossref| Others

31. Kinney, J.P., Trivedi, M.K., Branton, A., et al. Overall skin health potential of the biofield energy healing based herbomineral formulation using various skin parameters. (2017) Ame J Life Sci 5(2): 65-74.

Pubmed| Crossref| Others

32. Singh, J., Trivedi, M.K., Branton, A., et al. Consciousness energy healing treatment based herbomineral formulation: A safe and effective approach for skin health. (2017) Amer J Pharmacology Phytotherapy 2(1): 1-10.

Pubmed| Crossref| Others

33. Trivedi, M.K., Branton, A., Trivedi, D., et al. A Systematic study of the biofield energy healing treatment on physicochemical, thermal, structural, and behavioral properties of magnesium gluconate. (2017) Int J Bioorganic Chem 2(3): 135-145.

Pubmed| Crossref| Others

34. Trivedi, M.K., Branton, A., Trivedi, D., et al. Chromatographic and spectroscopic characterization of the consciousness energy healing treated Withania Somnifera (ashwagandha) root extract. (2017) European J Biophysics 5(2): 38-47.

Pubmed| Crossref| Others

35. Trivedi, M.K., Patil, S., Shettigar, H., et al. The potential impact of biofield treatment on human brain tumor cells: A time-lapse video microscopy. (2015) J Integr Oncol 4: 141. Pubmed| Crossref| Others

36. Trivedi, M.K., Patil, S., Shettigar, H., et al. In vitro evaluation of biofield treatment on cancer biomarkers involved in endometrial and prostate cancer cell lines. (2015) J Cancer Sci Ther 7: 253-257.

Pubmed| Crossref| Others

37. Anagnos, D., Trivedi, K., Branton, A., et al. Influence of biofield treated vitamin $\mathrm{D}_{3}$ on proliferation, differentiation, and maturation of bone-related parameters in MG-63 cellline. (2018) Int J Biomed Eng Clinical Sci 4(1): 6-14. Pubmed| Crossref| Others

38. Lee, A.C., Trivedi, K., Branton, A., et al. The potential benefits of biofield energy treated vitamin $\mathrm{D}_{3}$ on bone mineralization in human bone osteosarcoma cells (MG-63). (2018) Int J Nutr Food Sci 7(1): 30-38.

Pubmed| Crossref| Others
39. Stutheit, M.E., Trivedi, K., Branton, A., et al. Biofield energy treated vitamin $\mathrm{D}_{3}$ : Therapeutic implication on bone health using osteoblasts cells. (2018) Ame J Life Sci 6(1): 13-21.

Pubmed| Crossref| Others

40. Stenn, K.S., Paus, R Controls of hair follicle cycling. (2001) Physiol Rev 81(1): 449- 494.

Pubmed| Crossref| Others

41. Inui, S., Fukuzato, Y., Nakajima, T., et al. Identification of androgen-inducible TGF-beta1 derived from dermal papilla cells as a key mediator in androgenetic alopecia. (2003) J Investig Dermatol Symp Proc 8(1): 69-71.

Pubmed| Crossref| Others

42. Gao, J., DeRouen, M.C., Chen, C.H., et al. Laminin-511 is an epithelial message promoting dermal papilla development and function during early hair morphogenesis. (2008) Genes Dev 22(15): 2111-2124.

Pubmed| Crossref| Others

43. Choi, S.J., Cho, A.R., Jo, S.J., et al. Effects of glucocorticoid on human dermal papilla cells in vitro. (2013) J Steroid Biochem Mol Biol 135(1): 24-29.

Pubmed| Crossref| Others

44. Botchkarev, V.A., Kishimoto, J. Molecular control of epithelial-mesenchymal interactions during hair follicle cycling. (2003) J Investig Dermatol Symp Proc 8(1): 46-55. Pubmed| Crossref| Others

45. Rastegar, H., Ashtiani, H.A., Aghaei, M., et al. Herbal extracts induce dermal papilla cell proliferation of human hair follicles. (2015) Ann Dermatol 27(6): 667-675. Pubmed| Crossref| Others

46. Bang, C.Y., Byun, J.W., Kang, M.J., et al. Successful treatment of temporal triangular alopecia with topical minoxidil. (2013) Ann Dermatol 25(3): 387-388. Pubmed| Crossref| Others

Submit your manuscript to Ommega Publishers and we will help you at every step:

- We accept pre-submission inquiries

- Our selector tool helps you to find the most relevant journal

- We provide round the clock customer support

- Convenient online submission

- Thorough peer review

- Inclusion in all major indexing services

- Maximum visibility for your research

Submit your manuscript at

OMMEgA Publishers

https://www.ommegaonline.org/submit-manuscript 